\title{
Extensional mechanics of continental lithosphere
}

\author{
Richard I. Walcott \\ Research School of Earth Sciences, Victoria University of Wellington, New Zealand
}

\begin{abstract}
Neogene continental extension in New Zealand and western North America occurs within a wide plate boundary zone between major plates, one continental and the other oceanic, and involves very substantial increases in area of the continental lithosphere. Separating the extending region from the adjacent oceanic plate is a strip of continental rocks some 200 to $300 \mathrm{~km}$ wide, parts of which have moved outward up to $400 \mathrm{~km}$ away from the parts of the plate boundary zone this frontal strip increase in area. Between the extending and non-extending case of New Zealand the cause of the extension is theen rotated which is observed paleomagnetically. In the overlying continental plate has been prevented from following the rollback of the oceanic lithosphere where the on either end of the subduction zone. In the case of western North America it has trench by continental collision of the extension is the previously thickened case of western North America it has been supposed that the cause thus making its own room. This hypothe continental crust flowing outwards through its own potential energy, extended and others have not. Like the extension in be a passive response to the relative motion of the major plates and that North American extension is inferred to is primarily produced by drag of the Pacific on the North American plate.
\end{abstract}

\section{Introduction}

A number of different lines of evidence now reveal huge extensional and compressional displacements in continental lithosphere, amounting in some cases to several hundred kilometres, that have occurred in quite short periods of geological time. These include paleomagnetic studies of rotation around vertical axes, structural analysis of displacement in sections, changes in crustal thickness, and present-day geodetic and seismic-moment studies.

It is the purpose of this paper to compare and contrast distinctive tectonic features in two areas of geologically recent, and currently active, extension of this deformation so as to infer the principal tectonic mechanisms that control extension in continental crust. The two regions, the North Island of New Zealand in the last $4 \mathrm{Ma}$ and western North America in the last $20 \mathrm{Ma}$, differ in both timing and size but there are common features and problems - the most notable of which is the room problem - how is the change of area accommodated that is the geometrical consequence of the extension? This reduces to the fundamental issue which is whether the spreading is active -i.e. the extending volume of rock made room for itself, or passive and it merely filled a space produced by unrelated forces. It is concluded that the dominating mechanism is provided by the motion of the bounding plates which are themselves controlled by subduction and that the continental deformation is essentially passive.

\section{North Island, New Zealand}

The area of extension in New Zealand is the Central Volcanic Region of the North Island (fig. 1). It is a continuation of back-arc spreading in the Havre trough to the northeast in the oceanic 


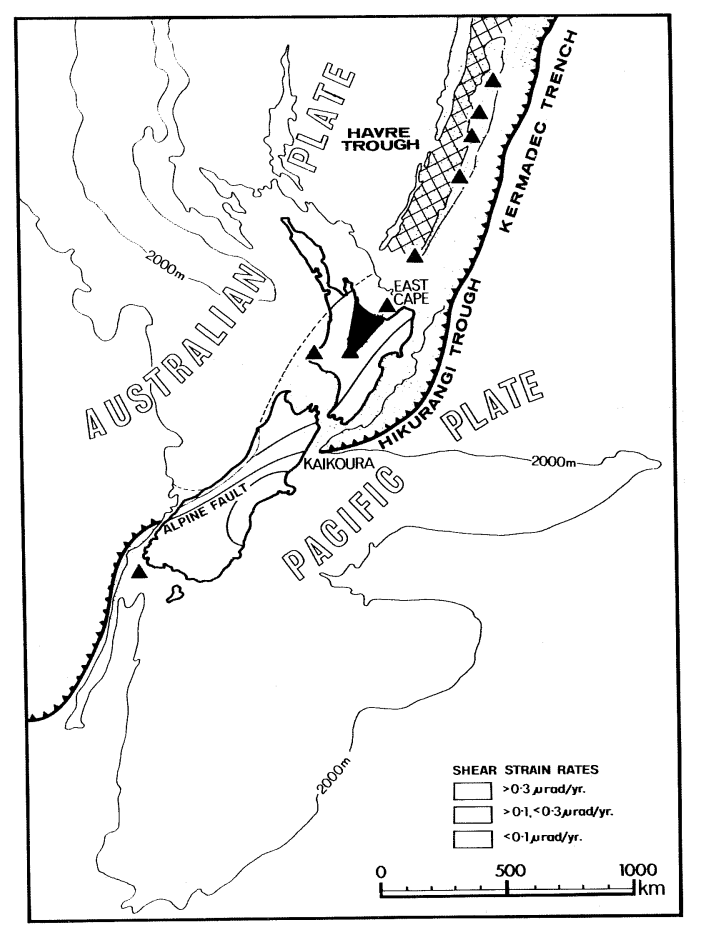

Fig. 1. The Central Volcanic Region is triangular in shape with base along the coast towards the Havre trough and apex at Mt. Ruapehu, an andesite cone in the centre of the North Island marked by a solid triangle. The Havre trough is an active back-arc marginal basin formed since the mid Pliocene. The Hikurangi margin, an active subduction zone, lies along the east of the New Zealand from East Cape to Kaikoura.

rocks behind the Kermadec arc. Stern (1985), Stern and Davey (1987) describe the structure of the Central Volcanic Region the main features of which are listed below.

Plate motion. The subduction zone on the east of New Zealand has been active for the whole of the Neogene and was initiated around 23 Ma ago (Walcott 1984b; Rait et al., 1991). It represents a continuation of the Tonga-Kermadec system and terminates near Kaikoura in the northern South Island (fig. 1). Reconstruction of the relative positions of Pacific and Australian plates 10 and $20 \mathrm{Ma}$ ago based on the finite Euler rotations given by Stock and Molnar (1982) show how the plate boundary has evolved over that time period (fig. 2). Rotation of the Hikurangi margin through about $60^{\circ}$ in the last $20 \mathrm{Ma}$ is required in order to link the end of the Kermadec trench to Kaikoura. While the Kermadec arc rotates with the Australian plate $(1 \% \mathrm{Ma})$ the Hikurangi margin has had to rotate three times as fast.

Structural analysis. The width of the Havre trough immediately to the north of the Central Volcanic Region is about $70 \mathrm{~km}$ and the oldest magnetic anomaly identified in the trough is $2^{\prime}$ (Malahoff et al., 1982) which is about 3.5 Ma old. The Central Volcanic Region, bounded by steep gravity gradients at the margins of the volcanically and geothermally active region, is triangular in shape with apex in the centre of the North Island at Mt. Ruapehu and base along the coastline south of the Havre trough (fig. 1).

This is a region of exceedingly high heat flow, about 12 times normal, thin crust and active tectonics. It is covered in ignimbrite sheets erupted in the last million years or so. Older rocks are not exposed within the Central Volcanic Region excepting small, poorly exposed outliers. Consequently estimating the amount of extension by mapping has not been possible. Judging from the width of the Havre trough a total extension along the base of the triangular area of about $70 \mathrm{~km}$ is indicated with progressively less toward the apex.

Present rate of extension. The Central Volcanic Region is a region of extensional strain observed geodetically through the comparison of modern and older triangulation networks. Over the $120 \mathrm{~km}$ width of the Central Volcanic Region along the coast the shear strain rates average 0.15 microstrain/a equivalent to a rate of extensional displacement of the east relative to the Australian plate on the west of $18 \mathrm{~mm} / \mathrm{a}$ with a standard error of about $40 \%$ (fig. 3) (Walcott, 1984a). The average extension rate in the Havre trough is similar $(22 \mathrm{~mm} / \mathrm{a})$. The rate is likely to decrease with the width of the Central Volcanic Region to the south and we infer that it is opening in a triangular manner with the east side rotating relative to the western about a hinge in the vicinity of Mt. Ruapehu.

Crustal thickness. Reversed refraction profiles from the Bay of Plenty coastline to Lake Taupo near Ruapehu in the centre of the North Island indicate a velocity structure of a $15 \mathrm{~km}$ thick crust with a velocity of $6.8 \mathrm{~km} / \mathrm{s}$ overlying 


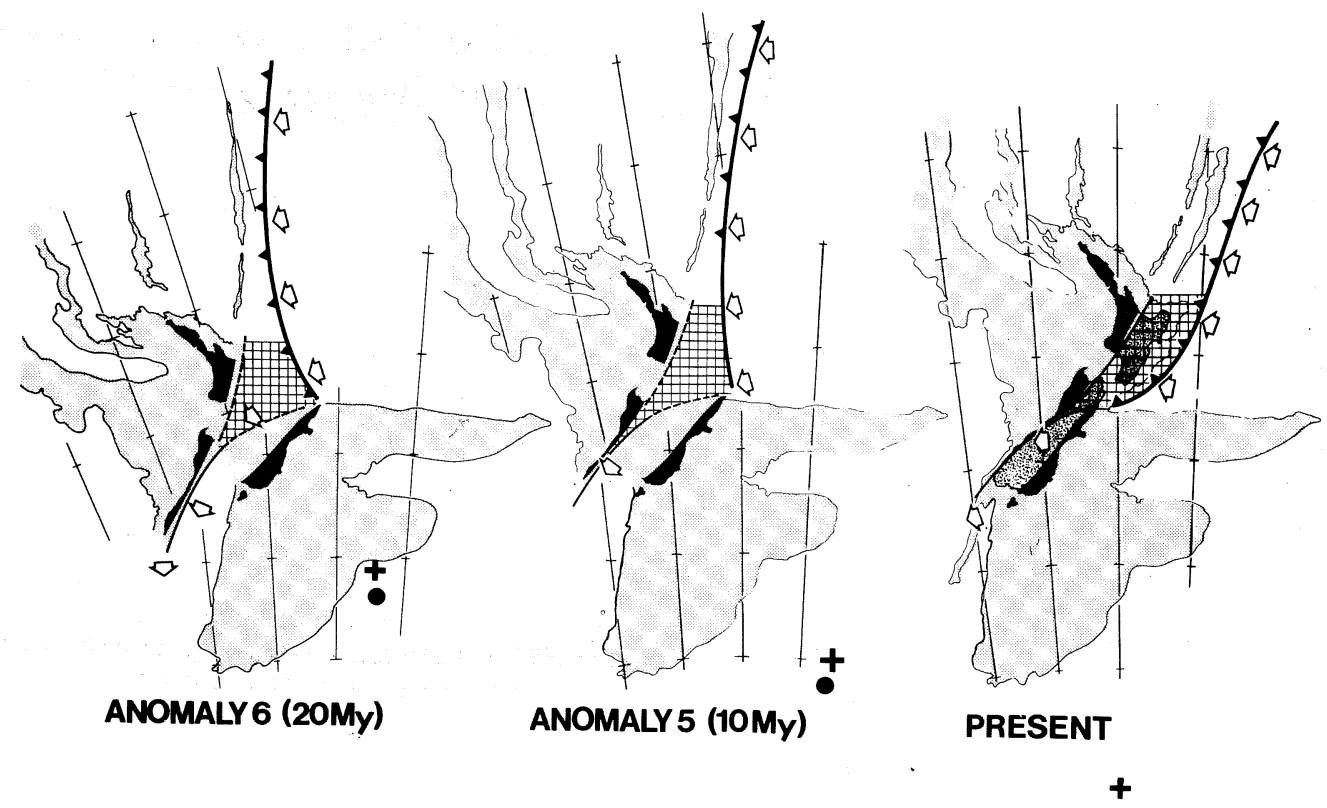

Fig. 2. Reconstruction of the New Zealand region for period of 10 and $20 \mathrm{Ma}$. The Pacific plate is held fixed and the Australian plate is moved as calculated from the finite rotation parameters of Stock and Molnar (1982). The finite rotation pole is shown as a filled circle and the estimated instantaneous pole is shown as a cross. The relative motion between the plates is accommodated on the trench marked with teeth and in the plate boundary zone in the continental rocks shown hatchured. The Australian plate rotates relative to the Pacific plate about $20 \mathrm{Ma}$.

a presumed mantle of $7.6 \mathrm{~km} / \mathrm{s}$ (Stern and Davey, 1987).

Paleomagnetic rotations. Studies of late Cenozoic sedimentary rocks along the east coast of the North Island adjacent to the Central Volcanic Region reveal rotations that increase with time. The rate of rotation is about $70 / \mathrm{Ma}$ today although it was less than that (about $2^{\circ} / \mathrm{Ma}$ ) prior to about $5 \mathrm{Ma}$ ago (Wright and Walcott, 1986; Walcott, 1987). East Cape itself (fig. 4 and 5) has not rotated significantly with respect to the Australian plate and the opening of the Havre trough is therefore inferred to have been by eastward translation of the arc relative to the plate. The boundary between the rotated, Wairoa domain (fig. 6), and the unrotated, Raukumara domain is a band of complex geology trending northeastward to the coast of the Central Volcanic Region.

\section{Western North America}

Plate motions. Stock and Molnar (1988) describe the displacement of the Pacific and North American plates in the last 30 Ma since the plates were in direct contact across the proto-San Andreas fault. Their calculations are reproduced in fig. 7 showing the past locations (with estimated uncertainties) of a point which today lies near Cape Mendocino at times of magnetic anomalies 3 (5Ma), 5 (10Ma) and 6 (20Ma). Also drawn in this diagram are lines of azimuth 145 and 140 which bound the trend of the San Andreas system north of the big bend, the trend of the San Andreas being variously given as N350 and N400W (Wallace, 1990). This diagram shows that in the last $5 \mathrm{Ma}$ the motion of the Pacific plate in northern California has been substantially parallel to the trend of the San Andreas fault - if 


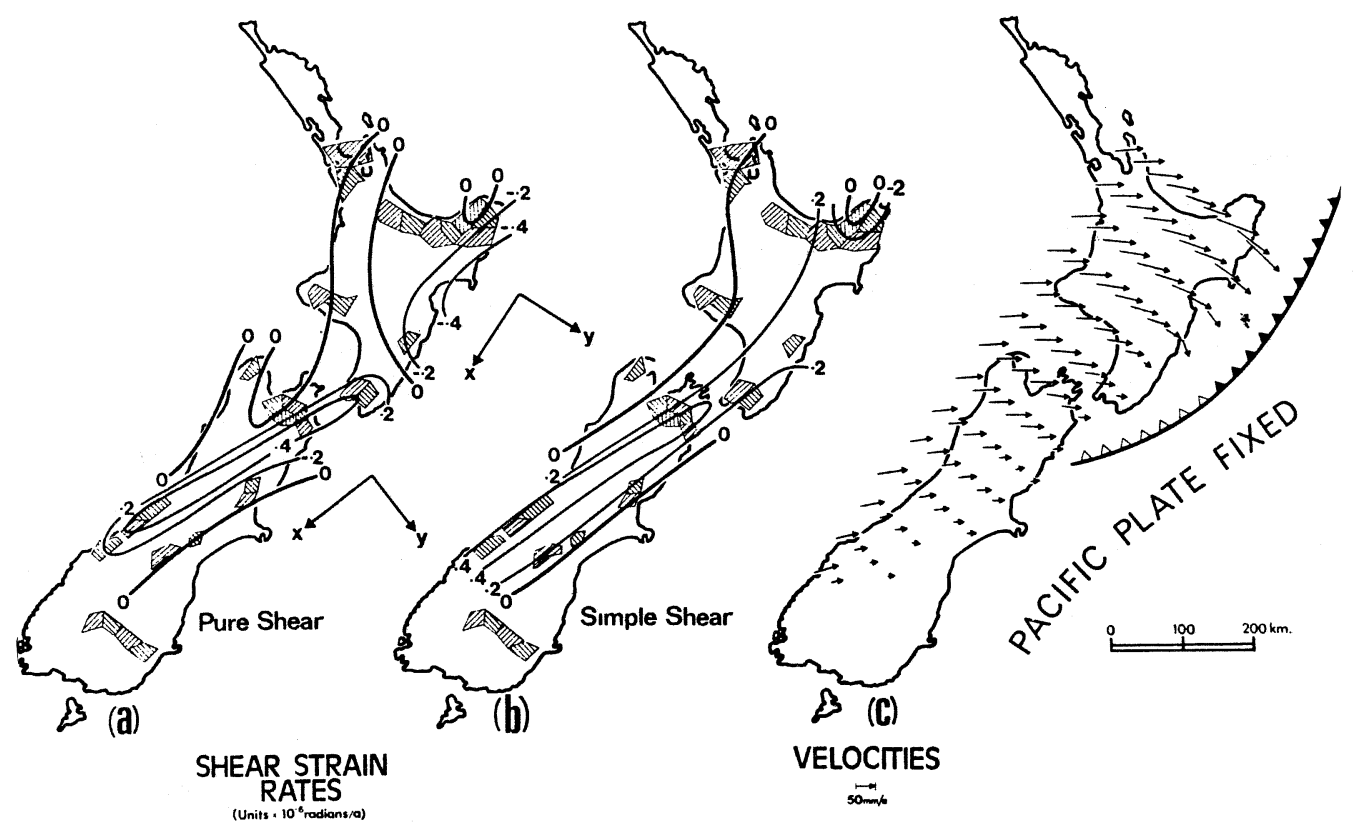

Fig. 3. Geodetic strain rates (in microradians/a) from Walcott (1984a). a) The shortening (positive) and extensional (negative) component normal to the plate boundary; b) the simple shear component parallel to the plate boundary (positive, dextral); and c) kinematic representation of the deformation of New Zealand. The average rate of extensional strain in the three blocks crossing the Central Volcanic Region is 0.15, while the average rate of simple shear is less than 0.05 microradians/a.

anything, there is a slight component of shortening normal to the fault, but between then and the time of anomalies 5 and 6 there has been a significant component of motion of the Pacific plate away from North America normal to the San Andreas trend. At $20 \mathrm{Ma}$ the displacement parallel to the fault is $(850 \pm 70) \mathrm{km}$ and normal to the fault it is $(185 \pm 95) \mathrm{km}$. Some $35 \mathrm{~km}$ error is assigned to the uncertainty in the trend of the San Andreas system and the remainder is due to uncertainties in the computed position of the point. The values for other times can be readily scaled from the diagram.

The Pacific plate has been in direct contact with the North American plate during the Neogene around the Queen Charlotte Islands also. There the motion has been very largely strike slip with, if anything, a component of shortening normal to the plate boundary (fig. 8) throughout the Late Cenozoic.

Structural analysis. Wernicke et al. (1988) provide a well-constrained estimate of the extension in the Basin and Range at latitude $360^{\circ} \mathrm{N}$, in the vicinity of Las Vegas, of $247 \mathrm{~km}$ with an estimate of error (given as a range of possible values, approximating $95 \%$ confidence limits) of $\pm 56 \mathrm{~km}$ an azimuth of extension 2870 relative to the Colorado Plateau, and, therefore, effectively, the North American craton (fig. 8). The present width of the Basin and Range Province along this azimuth is about $360 \mathrm{~km}$ so the extension is $200 \%$ to $400 \%$. Most of the extension is considered to have occurred in the last $15 \mathrm{Ma}$ giving an average rate of about $17 \mathrm{~mm} / \mathrm{a}$. The present rate of extension is very much less than this.

Present rate of extension. The present rate of extension derived from seismic-moment tensors of historic earthquakes by Smith at al. (1989) is estimated to be 8 to $10 \mathrm{~mm} / \mathrm{a}$ in an east-west direction. A similar rate, $7.4 \mathrm{~mm} / \mathrm{a}$, is derived from VLBI studies (Beroza et al., 1985). 


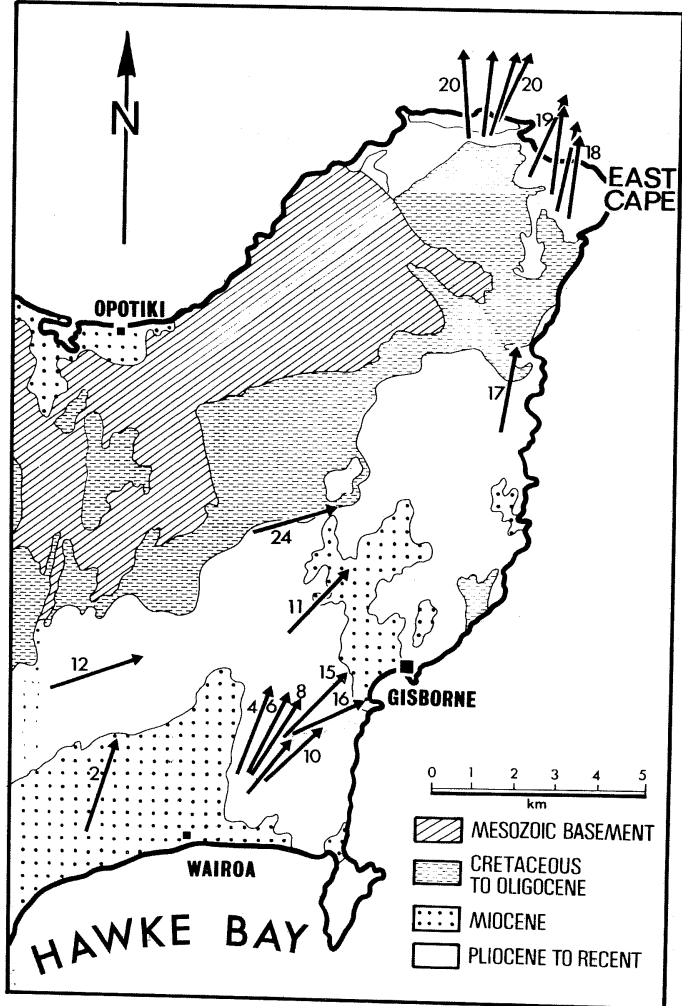

Fig. 4. The direction of paleomagnetic declination in sedimentary rocks on the east coast of the North Island. Age of the sediments in Ma is given alongside each location. Two distinct rotational domains are present, Raukumara domain in the northeast where there has been no significant rotation in the last 20 Ma relative to the Australian plate, and Wairoa domain. See also fig.5.
Together with the above estimate of Late Cenozoic extension the implication is that the rate was considerably greater, around $20 \mathrm{~mm} / \mathrm{a}$, in the period 15 to $5 \mathrm{Ma}$ with about half that in the last $5 \mathrm{Ma}$.

A principal source of uncertainty in estimating displacement from seismic-moment studies is the effect of a possible uniform rotation. The faults themselves may be rotating and if so the direction of extension could differ considerably from these estimates.

Slip on the San Andreas fault. The total slip across the San Andreas fault in the last $20 \mathrm{Ma}$ from various sources is summarised by Irwin (1990) and is 315 to $325 \mathrm{~km}$ based on several lines of evidence. This is very much less than the $(850 \pm 70) \mathrm{km}$ of motion of the Pacific plate relative to North America in the same period. The discrepancy of more than $500 \mathrm{~km}$ must be accommodated elsewhere.

The displacement of $250 \mathrm{~km}$ at $287^{\circ}$ azimuth for the Sierras relative to the Colorado Plateau given by Wernicke et al. (1988) decribed above accounts for $200 \mathrm{~km}$ parallel, and $145 \mathrm{~km}$ normal to the San Andreas trend. Thus virtually all the normal component of motion of the Pacific relative to the North American plate is accounted for by the measured extension in the south of the Basin and Range but there remains some $325 \mathrm{~km}$ of motion parallel to the trend.

How much of the $325 \mathrm{~km}$ of excess relative plate motion $(850 \mathrm{~km})$ over and above that accommodated on the San Andreas (325 km) and within the Basin and Range $(200 \mathrm{~km})$ is taken up

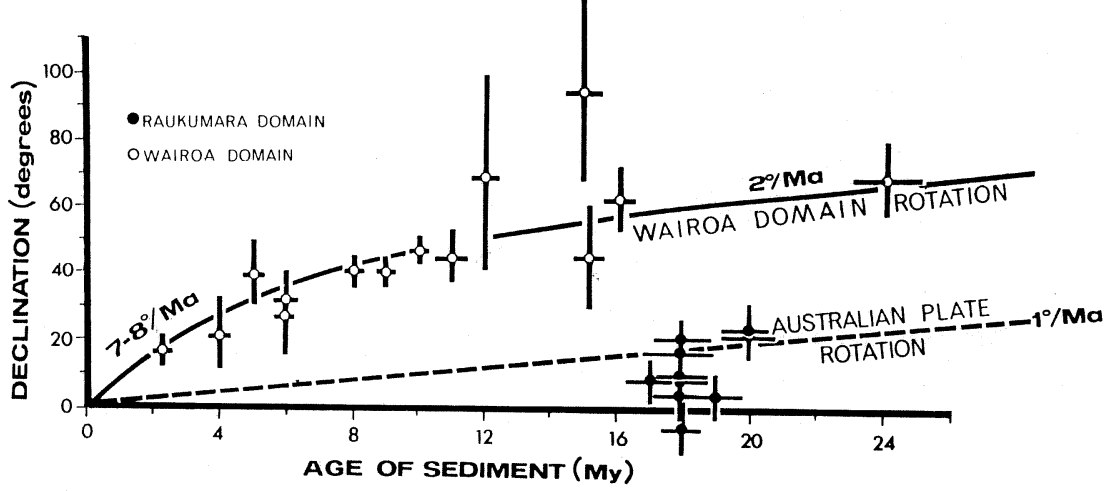

Fig. 5. Declination plotted as a function of age of sedimentary rock. The Wairoa domain has rotated at about $7^{\circ} / \mathrm{Ma}$ for the last $4 \mathrm{Ma}$ and at about $2^{\circ} / \mathrm{Ma}$ before that. A total rotation of about $60^{\circ}$ relative to the Pacific plate or $40^{\circ}$ relative to the Australian plate over the last $20 \mathrm{Ma}$ is indicated. 


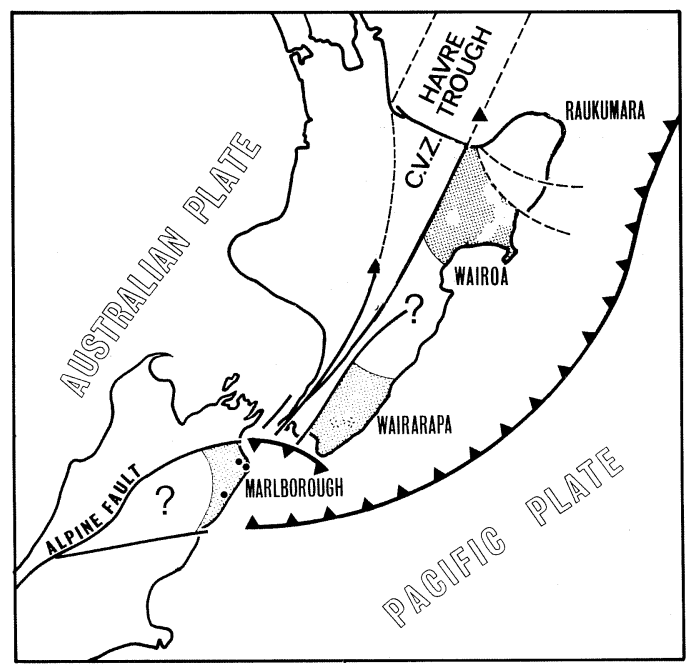

Fig. 6. The opening of the Central Volcanic Region (C.V.Z.) resulted in the rotation of the Wairoa domain. Raukumara domain has not rotated as the opening of the Havre trough has been caused by a simple translation to the southeast. The boundary between the rotated Wairoa and unrotated Raukumara domain lies between the dashed lines.

on faults west (like the San Gregorio-Hosgri) and east (like the Owen Valley fault) of the San Andreas is uncertain. In the reconstructions of fig. 9 the excess is split $125 \mathrm{~km}$ to the west on the San Gregorio-Hosgri fault etc. and $200 \mathrm{~km}$ on the east of the San Andreas. This means that the rocks immediately northeast of the San Andreas have themselves moved relative to the North American craton and plate some $400 \mathrm{~km}$ in the last 20 Ma. Thus the «California Block» and Sierra Nevada are taken in fig. 9 as having moved in the last $20 \mathrm{Ma} 450 \mathrm{~km}$ to the southeast relative to the Pacific plate and $400 \mathrm{~km}$ to the northwest relative to the North American plate.

Crustal thickness. The average crustal thickness in the Intermontane Region of the western United States is about $30 \mathrm{~km}$ according to Pakiser (1989) compared to $40 \mathrm{~km}$ in the adjacent unextended region. The region of thinner crust extends from the Sierra Nevada on the west to the Rocky Mountains on the east and is about $600 \mathrm{~km}$ in width. An extension of $150 \mathrm{~km}$ could account for crustal thinning of this magnitude but there are large uncertainties in this sort of estimate, in particular as to how much crustal underplating by igneous activity may have occurred. A large part of the eastern Basin and Range is underlain by some $10 \mathrm{~km}$ of material above the Moho with a velocity of 7.4 to $7.6 \mathrm{~km} / \mathrm{s}$ (Smith et al., 1989) suggestive of underplating. The amount of crustal thinning by extension may therefore be $50 \%$ implying an extension of $300 \mathrm{~km}$.

Paleomagnetism. There is an extensive literature on the anomalous declinations (and inclinations) of Cenozoic rocks in western North America and the structural interpretation of the implied rotations, starting with Beck (1976), and here only a brief summary is given. Along the Coastal Ranges south of Seattle the declination of mid-Miocene rocks is about 300 clockwise of the direction expected for the North American

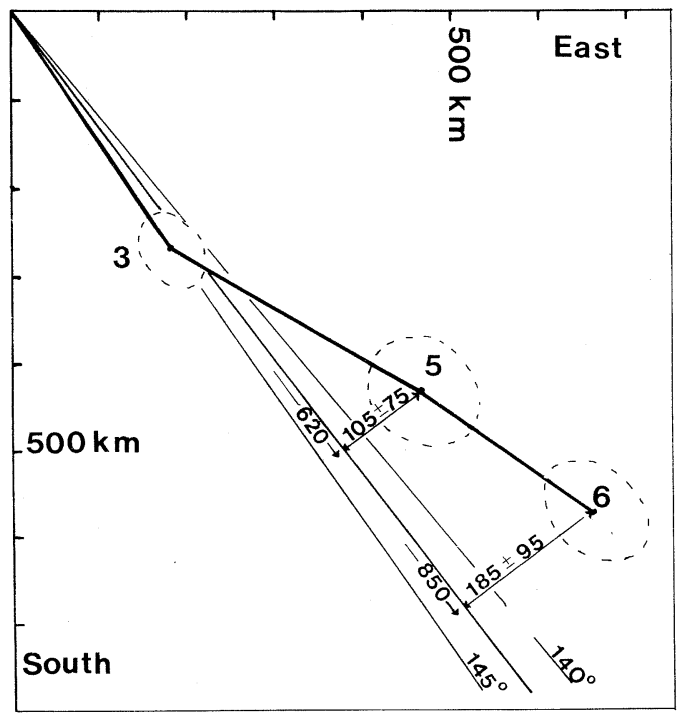

Fig. 7. The positions of a point which is today near Cape Mendocino on the Pacific plate at $45^{\circ} \mathrm{N}$ and $125^{\circ} \mathrm{W}$ calculated for the times of magnetic anomalies 3,5 and 6 from Stock and Molnar (1988). Their error estimates are shown as dashed ellipses. Drawn through the present-day position of the point is a line parallel to the trend of the northern section of the San Andreas fault system. It is bounded by lines at $145^{\circ}$ and $140^{\circ}$ azimuth which are estimates of the uncertainty in the trend. Since anomaly 6 (20 Ma ago) the Pacific plate has moved relative to the North American plate 850 $\mathrm{km}$ parallel to the San Andreas trend and some $185 \mathrm{~km}$ normal to it. 


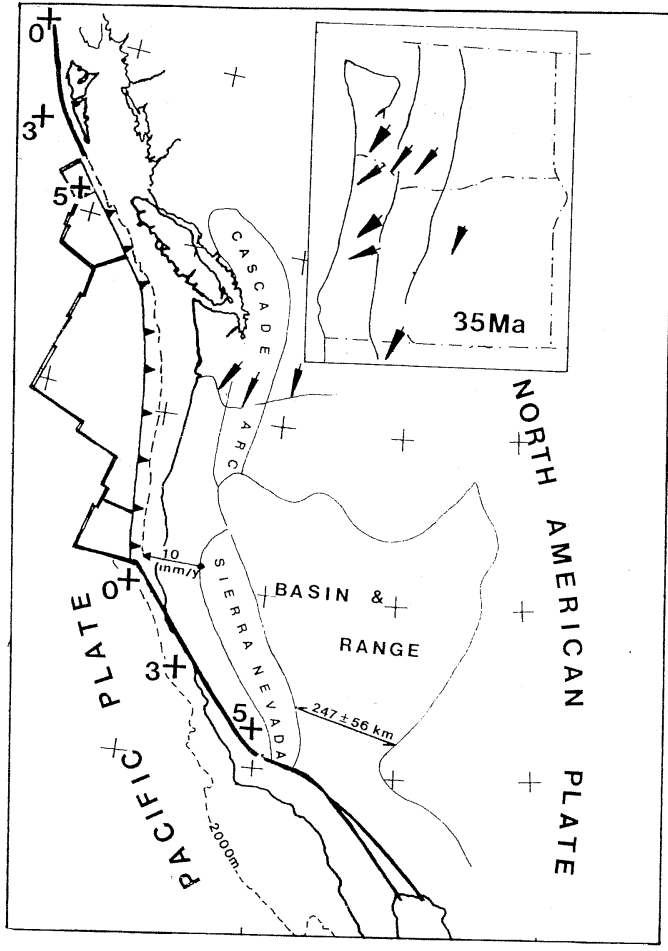

Fig. 8. Summary map for western North America. The elongate solid triangles are paleomagnetic declinations; in the insert, for rocks of Eocene and Oligocene age and on the main map for rocks of midMiocene age (selected from Wells, 1990). The displacement shown for southern Basin and Range is from Wernicke et al. (1988), and the present-rate east-west displacement for the northern Sierra Nevada is from Smith et al. (1989). The position of two points today ( 0 ) on the Pacific plate near the plate boundary with the North American plate is shown for anomalies 3 and 5. In the north the motion of the Pacific plate has been parallel, with anything a shortening component, while in the south, adjacent to the Basin and Range, there has been a substantial component of extension normal to the boundary.

plate. In the Cascade arc and the Intermontane region beyond, the anomalous declinations progressively increase from near zero on the Columbia River Plateau westward to the coast along the Columbia River over a distance of about $250 \mathrm{~km}$ (Wells, 1990).

Late Eocene and early Oligocene rocks have an anomalous declination of about $50^{\circ}$ in the
Coast Range and the amount of anomalous declination also decreases eastward (Wells and Heller, 1988). If the increasing rotation is due to a northeastward gradient in displacement, then extensional strain of some $80 \%$ in the arc behind the Coastal Ranges is implied. Given the obvious extension in the Cascades and westernmost Columbia River Plateau this explanation of the rotation of the Coastal Ranges as a uniform rotation of a coherent block (Gromme et al., 1986) is reasonable and attractive.

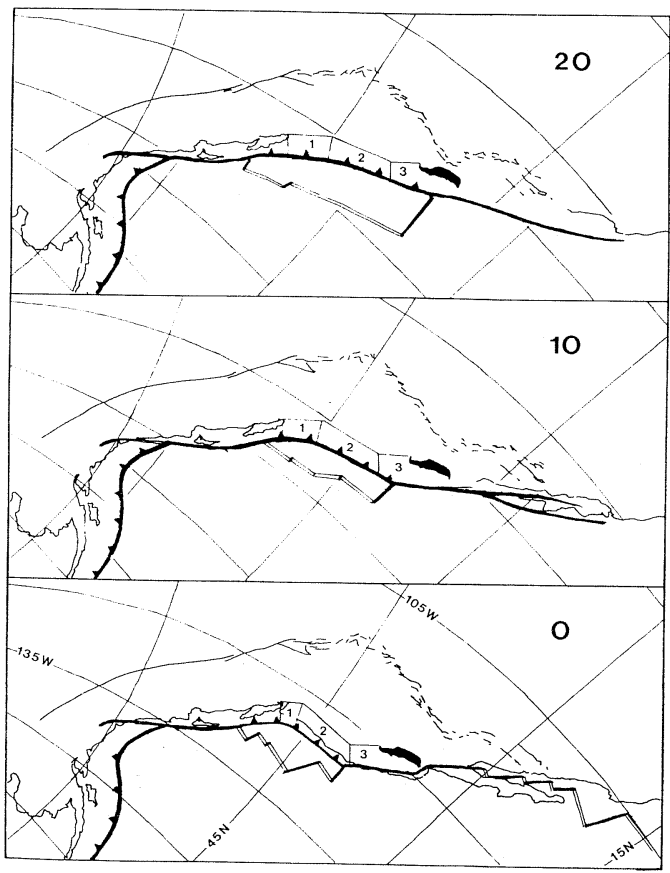

Fig. 9. Reconstruction of the Pacific and Western North America for 20 and 10 Ma Before Present. The projection and map for the present day $(0 \mathrm{Ma})$ is modified from Atwater (1970), and shows outlying faults bounding the area of active Cenozoic extension. The reconstruction of the major plates is based on Stock and Molnar (1988). No detail is shown for the Intermontane Region and the reconstructions show only the position of coherently deforming blocks along the western seaboard. 1 is the Olympic block that was strongly shortened in the Late Cenozoic; 2 is the Oregon-Washington Coastal Block that rotated strongly during the Cenozoic; 3 is the Californian Block and includes the Sierra Nevada in solid black that was translated, with little rotation, northwestward away from the North American craton during the Cenozoic. 


\section{Discussion}

Taken together, structural studies, presentday rates of displacement, crustal thickness, and particularly, paleomagnetic data give strong indication for the existence and timing of large extensional and strike-slip displacements of the western margin of the North America relative to the craton (fig. 9). The «California block» which includes the Sierra Nevada and lithosphere up to the San Andreas (block 3 in fig. 9) appears to have moved about $200 \mathrm{~km}$ orthogonal and 400 $\mathrm{km}$ parallel to the San Andreas trend in the last 20 Ma relative to the North American craton. The 300 rotation of Washington and Oregon Coastal Ranges (block 2 in fig. 9) in the last 15 Ma can be readily accounted by this northwestward displacement of the California block and the even larger rotations of the Late Eocene and Oligocene rocks imply active extension and shear within the Intermontane region in the Paleogene too. The Olympic block (block 1 in fig. 9) has not rotated but has to accommodate the very considerable shortening and internal deformation required by the northward motion of block 2 and 3 and the rotation of 2. Underthrusting of Vancouver Island and crustal thickening to form the mountains of the Olympic Peninsula are the products of this deformation. Northward motion of the Coastal Ranges block has been suggested to be due to the oblique convergence of the underlying Juan de Fuca plate but the oblique nature of the motion is a fairly recent development arising because of the rotation of the block. Earlier in the Neogene the convergence would have been normal to the trench and, in this regard, is very similar to the Hikurangi margin. It is more likely that the northward displacement of the coastal blocks as well as the rotation is due to coupling across the Pacific-North America boundary in the vicinity of California. It is the motion of the Pacific that partly drags these coastal blocks northward against the bulwark of the Canadian Coastal Ranges.

In North America the very considerable increase in area required by the extension of the Intermontane Region has been accommodated largely along the Neogene subduction zone at the northwestern margin of the United States and to a lesser, but still significant, extent by the ortho- gonal component of separation of the Pacific from the North American plate in the Miocene. Northward, rotation evident in anomalous paleomagnetic declinations ceases around southern Puget Sound, about $100 \mathrm{~km}$ south of Vancouver Island, and as expected, Neogene extension in the hinterland dies out there too. There, the trend of the subducted plate swings through $30^{\circ}$ and it has evidently rotated with the overlying rocks of the Coast Range.

In New Zealand the increase in area due to extension of the Central Volcanic Region and back-arc spreading in the Havre trough has been accommodated along the Kermadec-Hikurangi subduction zone. Kinematically, the rollback of the subduction Pacific plate is proceeding faster than the advance of the leading edge of the Australian plate and we can ask what is preventing the Australian plate following the rollback in the last $4 \mathrm{Ma}$ as it did in the preceding $25 \mathrm{Ma}$ when there was no back-arc spreading? An answer is that the spreading is due to the recent collisions at the north end of the boundary of the OntongJava Plateau with New Guinea, and at the south end across the Southern Alps. Everywere between these two areas of collision the $\mathrm{Pa}$ cific/Australian plate boundary has an additional extensional component in the form of actively opening marginal basins. The only special thing about the Central Volcanic Region is that it is occurring in continental crust. Between Hawke Bay and Kaikoura the plate boundary is one of shortening rather than extension and this is manifest in the rotation of the Hikurangi margin. At Ruapehu, the southernmost limit of extension along the Australian/Pacific plate boundary, the speeds of the Pacific and Australian plates match. In this view, the forces that dominate the dynamics of extension arise from the subduction process and collision on the plate boundary. The coherent rotation and/or translation of the active margin occurs because the underlying subducted plate provides a stable base on which the obducted rocks are passively rotated along with the subducted plate itself.

It is possible to view the North American extension in much the same terms. Basically, the question posed in western North America is why part of the area affected by the Laramide orogeny has been stretched, as in western United States 
and Mexico, and part not, as in western Canada? An answer is provided by considering the plate motions. Throughout the Neogene the motion of the Pacific relative to North American plate in western Canada has been parallel to the plate boundary and, if anything, with shortening rather than extension normal to the plate boundary. This transform motion occurred as far south as Vancouver Island from the reconstructions of Stock and Molnar (1988) and as far back as anomaly 18 . But south of that there has been almost continuous subduction along the Oregon and Washington margin, although slow, in the period from anomaly 10 (30 Ma) to 5 (10 Ma). And in California there was strong, early separation of the plates that required extension in the continental plate.

Thus as the Pacific plate moved northwestward relative to the North American craton the western margin of North America in the vicinity of California followed but at about half the rate; slip on the San Andreas and other faults to the west accounting for the difference in rates there; sea-floor spreading along the margin of the $\mathrm{Pa}$ cific plate further north accounting for the difference in rates at the Pacific northwest. The motion of the Pacific or indeed any plate is dominated by the boundary forces of which the most important by far is the pull exerted by the subducting part of the plate (Harper, 1990). Thus the extension in North America arose where it did because the boundary forces acting on the Pacific plate pulled it away from the North American plate in the Miocene but further north along the Canadian margin the plate motion has prevented extension and the Canadian Cordillera remains essentially as they were the end of the Eocene.

\section{REFERENCES}

ATwATER, T.M. (1970): Implications of plate tectonics for the Cenozoic tectonic evolution of western North America, Geol. Soc. Am. Bull., 81, 3518-3536.

BECK, M.E. (1976): Discordant paleomagnetic pole positions as evidence of regional shear in the western Cordillera of North America, Am.J.Sci., 276, 694-712.

BerozA, G.C., T.H. Jordan, J.B. Minster, T.A. Clark and J.W. RYAN (1985): VLBI vector position data; application to western U.S. deformation, EOS Transactions A. G. U., 66, 848-849.

Gromme, C.S., M.E. BeCK, R.E. Wells and D.C. ENGEBRETSON (1986): Paleomagnetism of the Tertiary Clarno For- mation of Central Oregon and its significance for the tectonic history of the Pacific Northwest, J. Geophys. Res., 91, 14 089-14 103.

HARPER, J. (1990): Plate dynamics: Carribean map corrections and hotspot push, Geophys. J. Int., 100, 423-431.

IRWIN, W.P. (1990): The San Andreas Fault System, California: geology and plate tectonic development, U.S. Geol. Surv. Prof. Pap., 1515, 61-80.

Malahoff, A., R.H. Foden and H.S. Fleming (1982): Magnetic anomalies and tectonic fabric of marginal basins north of New Zealand, J. Geophys. Res., 87, 4109-4125.

PAKISER, L.C. (1989): Geophysics of the Intermontane system, Geol. Soc. Am. Mem., 172, 235-247.

RaIT, G., F. Chanier and D.W. WATERs (1991): Landwardand seaward-directed thrusting accompanying the onset of subduction beneath New Zealand, Geology, 19, 230-233.

SMith, R.B., W.C. NAGY, K.A. Julander, J.J. Viveiros, C.A. BARKER and D.G. GANTS (1989): Geophysical and tectonic framework of the eastern Basin and Range-Colorado Plateau-Rocky Mountain transition, Geol. Soc. Am. Mem., 172, 205-233.

STERN, T.A. (1985): A back-arc basin formed within continental lithosphere: The Central Volcanic Region of New Zealand, Tectonophysics, 112, 385-409.

SteRN, T.A. and F.J. DAVEY (1987): A seismic investigation of the crust and upper mantle structure within the Central Volcanic Region of New Zealand, New Zealand J. Geol. Geophys., 30, 217-231.

STOCK, J.M. and P. MolnaR (1982): Uncertainties in the relative motions of Australia, Antarctica and Pacific Plates since the Late Cretaceous, J. Geophys. Res., 87, 4697-4714.

STOCK, J.M. and P. MolnaR (1988): Uncertainties and implications of the Late Cretaceous and Tertiary position of North America relative to the Farallon, Kula and Pacific Plates, Tectonics, 6, 1339-1384.

WALCOTT, R.I. (1984a): The kinematics of the plate boundary zone through New Zealand: a comparison of short and long term deformation, Geophys. J. R. Astron.Soc., 79, 613-633.

WALCOTT, R.I. (1984b): Reconstruction of the New Zealand region for the Neogene, Paleog. Paleoclimat. Paleoecol., 46, 217-231.

WALCOTT, R.I. (1987): Geodetic strain and the deformational history of the North Island of New Zealand during the late Cainozoic, Philos. Trans. R. Soc. London, 321, 163-181.

Wallace, R.E. (1990): The San Andreas Fault system, California: general features, U.S. Geol. Surv. Prof. Pap., 1515, 3-12.

WELLS, R.E. (1990): Paleomagnetic rotations and the Cenozoic tectonics of the Cascade Arc, Washington, Oregon and California, J. Geophys. Res., 95, 19 409-19 417.

WELls, R.E. and P.L. HeLlER (1988): The relative contribution of accretion, shear, and extension to Cenozoic tectonic rotation in the Pacific Northwest, Bull. Geol. Soc. Am., 100, 325-338.

WERNICKE, B., G.J. AXEN and J.K. SNOw (1988): Basin and Range extensional tectonics at the latitude of Las Vegas, Nevada, Bull. Geol. Soc. Am., 100, 1738-1757.

WRIGHT, I.C. and R.I. WALCOTT (1986): Large tectonic rotation of part of New Zealand in the last $5 \mathrm{Ma}$, Earth Planet. Sci. Lett., 80, 348-352. 